\title{
Chorological contributions for some narrow-range endemic plant taxa in Turkey
}

Ergin HAMZAOĞLU ${ }^{1 *} \odot$, Murat KOÇ ${ }^{2} \odot$

${ }^{1}$ Gazi University, Gazi Faculty of Education, Department of Science Education, Ankara, Turkey

${ }^{2}$ Ankara Ylldırım Beyazlt University, Public Health Institute, Department of Traditional, Complementary and Integrative Medicine, Ankara, Turkey

*erginhamzaoglu@yahoo.com, ${ }^{2}$ aybumaratkoc@hotmail.com

Received : 09.09.2020 Accepted : 05.10.2020 Online : 08.10 .2020

\section{Türkiye’deki bazı dar yayılışı endemik bitki taksonları için korolojik katkılar}

\begin{abstract}
The taxonomy of narrow endemic plant taxa, chorology and protective biology are an important contribution for every new population determined. Here, new population information from Turkey has been given for a total of 5 narrow-range endemic plant taxa, led by Aethionema dumanii (Brassicaceae), Astragalus aytatchii (Fabaceae), Salvia halophila (Lamiaceae), Sedum hewittii (Crassulaceae) and Senecio olympicus (Asteraceae). Furthermore, some features and ecological preferences, localities, distribution map and images of the species are given.
\end{abstract}

Key words: Endemic, chorology, new populations, Turkey

Özet: Tespit edilen her yeni popülasyon, dar endemik taksonların taksonomisi, korolojisi ve koruma biyolojisi için önemli bir katkıdır. Burada Aethionema dumanii (Brassicaceae), Astragalus aytatchii (Fabaceae), Salvia halophila (Lamiaceae), Sedum hewittii (Crassulaceae) ve Senecio olympicus (Asteraceae) olmak üzere toplam 5 dar yayllsşl endemik bitki taksonu için Türkiye'den yeni popülasyon bilgileri verilmiştir. Ayrıca türlerin bazı özellikleri ve ekolojik tercihleri, lokaliteleri, yayılış haritası ve resimleri verilmiştir.

Anahtar Kelimeler: Endemik, koroloji, yeni popülasyonlar, Türkiye

Citation: Hamzaoğlu E, Koç M (2020). Chorological contributions for some narrow-range endemic plant taxa in Turkey. Anatolian Journal of Botany 4(2): 96-99.

\section{Introduction}

According to the International Union for Conservation of Nature (IUCN) criteria, the plant species, which continue their existence in nature and about which there is sufficient information, are evaluated in the threat categories, which are defined as Critically Endangered (CR), Endangered (EN), Vulnerable (VU), Near Threatened (NT) or Least Concern (LC). Among these, the CR, EN, and VU are categories, which should be protected. It is necessary to know the extent of the area of distribution and the number of individuals for being able to decide in which category a taxon is placed (IUCN Standards and Petitions Committee, 2019). Consequently, it is an important discovery, which includes for any species the categories of threat required for protection, to find new populations, and which directly affects the threat category of a known species. According to the IUCN, species, whose lineages are under threat, are evaluated from the aspect of 5 criteria that are listed from A to E. The discovery of new populations directly affects these criteria, especially A and $\mathrm{B}$. The A criterion is related to "decrease in population", whereas B is related to "extent of area of distribution" (IUCN Standards and Petitions Committee, 2019). The discovery of every new population increases the population number of the species and extends the area of distribution. Here, new distribution areas of 5 narrow-range endemic species were presented in order to contribute to the classification of the threat categories of the species.

\section{Materials and Method}

Here, the narrow endemic plant taxa given to new populations have been collected during the floristic activities performed at different times in different provinces of Turkey. Together with the detailed address to the extent possible in the section of the distribution information for taxa, their Global Positioning System (GPS) records have also been written. Furthermore, photographs have been given, which display diagnostic characters for the taxa. The specimens collected were delivered to the GAZI and ANK herbaria to be kept. The Google Earth application was used to assess the distribution areas of the species. The width of the distribution area was calculated with the aid of a polygon drawn to include all recognized species addresses.

\section{Results and Discussions}

\section{Brassicaceae}

Aethionema dumanii Vural \& Adigüzel, Turkish J. Bot. 19(4): 481 (1995), (IPNI, 2020).

Specimens examined: B6 Sivas: Between Şarkışla and Pınarbaşı (Malatya road), 37 S 282176-4322577, 1600 m, marl steppe, 8.8.2018, Koç 3480 \& Hamzaoğlu (GAZI, ANK).

When the flower and fruit characters and the habitat preferences stated in the original publication were taken into consideration, it was decided that the specimens collected from Sivas belong to Aethionema dumanii. According to the existing data, the species is an endemic plant, which prefers the marl and gypsum steppes between 840-1400 meters in Eskişehir, Ankara, and Afyonkarahisar (Vural and Adigüzel, 1995). According to the Flora of Turkey and the East Aegean Islands, since the species is a perennial, has unilocular fruits, is shorter than $30 \mathrm{~cm}$ and its 
fruits have the dimensions of 6-9 $\times 7-9 \mathrm{~mm}$, it resembles $A$. eunomioides (Boiss.) Bornm. (Hedge, 1965). However the leaves of A. dumanii are oblong-linear and alternately arranged (not ovate-spatulate or orbicular and the bottom leaves are not arranged opposite), the fruit edge is undulate, irregular crenate-dentate and the wings are at a width of 3$4 \mathrm{~mm}$ (not smooth and 1.5-2 mm) (Fig. 1). Together with the addition of the data for the new population, the upper elevation interval has reached 1600 meters, it was understood that its distribution continued towards the east and that the extent of its area of distribution became approximately $15.000 \mathrm{~km}^{2}$ (Fig. 2).

\section{Fabaceae}

Astragalus aytatchii Akan \& Civelek, Ann. Bot. Fenn. 38(3): 169 (2001), (IPNI, 2020).

Specimens examined: B8 Erzurum: Aşkale, N. of Yeşilova village, $37 \mathrm{~S}$ 642438-4422857, $1750 \mathrm{~m}$, gypsum-bearing steppe, 29.5.2019, Hamzaoğlu 7587 \& Koç (GAZI, ANK).

Astragalus aytatchii is a defined endemic species with specimens, which were collected from the surroundings of Hocabey Village, to the south of the Sivas Provincial Center (Fig. 3). This species, which belongs to the Alopecuroidei DC. (= Alopecias (Steven) Bunge) section, resembles A. elatus Boiss. \& Balansa (Akan and Civelek, 2001), since its peduncle is shorter than $5 \mathrm{~mm}$, its calyx is 8-10 $\mathrm{mm}$ long and it teeth are 3-5 $\mathrm{mm}$ long, the upper surface of its leaflets are without hairs and the lower surface is hairy, adpressed pilose, the stipules are $8-15 \mathrm{~mm}$ long, its bracts are $8-15 \mathrm{~mm}$ long, its standard is $18-19 \mathrm{~mm}$ long, and inflorescence is ovate or orbicular. However, in $A$. aytatchii, the bodies are $10-35 \mathrm{~cm}$ long (not $50-90 \mathrm{~cm}$ ), the

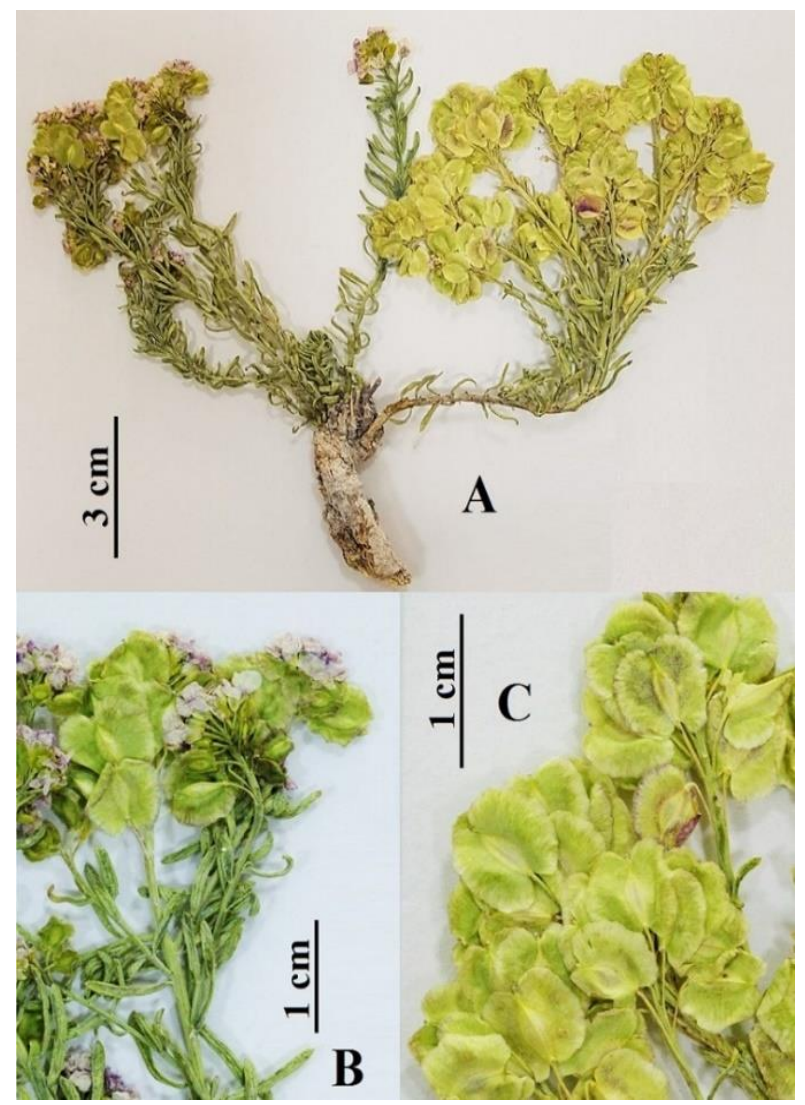

Figure 1. Aethionema dumanii - A. Habit, B. Inflorescence and C. Fruits.

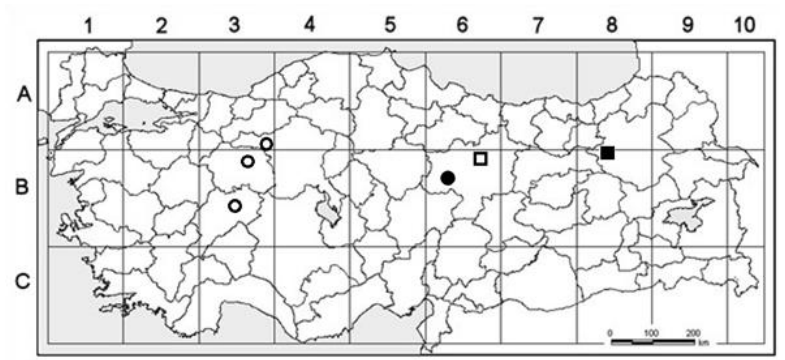

Figure 2. The known populations of Aethionema dumanii $(\mathbf{O})$ and the newly determined populations (O), the known populations of Astragalus aytatchi $(\mathbf{\square})$ and the newly determined populations (ם).

leaves are 6-18 cm long (not 19-36 cm), the leaflets are 914 pairs (not $20-24$ pairs), and the calyx is $8-10 \mathrm{~mm}$ long (not $12-18 \mathrm{~mm}$ ). It was stated that in the area where the species was defined on deep gypsum soil at an interval between 1500-1600 meters, approximately 100-150 mature individuals were found in the population and growing in an area of only 1000-1500 square meters. Together with the newly determined population at Aşkale, Erzurum Province, the extent of the area of distribution of the species became approximately $3000 \mathrm{~km}^{2}$ (Fig. 2). When both the type and the addresses given here are taken into consideration, it is observed that the species preferred steppes with gypsum. It can be stated that the probability of finding the species at other addresses in the steppes with gypsum betwe-en Sivas and Aşkale is rather high.

\section{Lamiaceae}

Salvia halophila Hedge, Notes Roy. Bot. Gard. Edinburgh 23: 58 (1959), (IPNI, 2020).

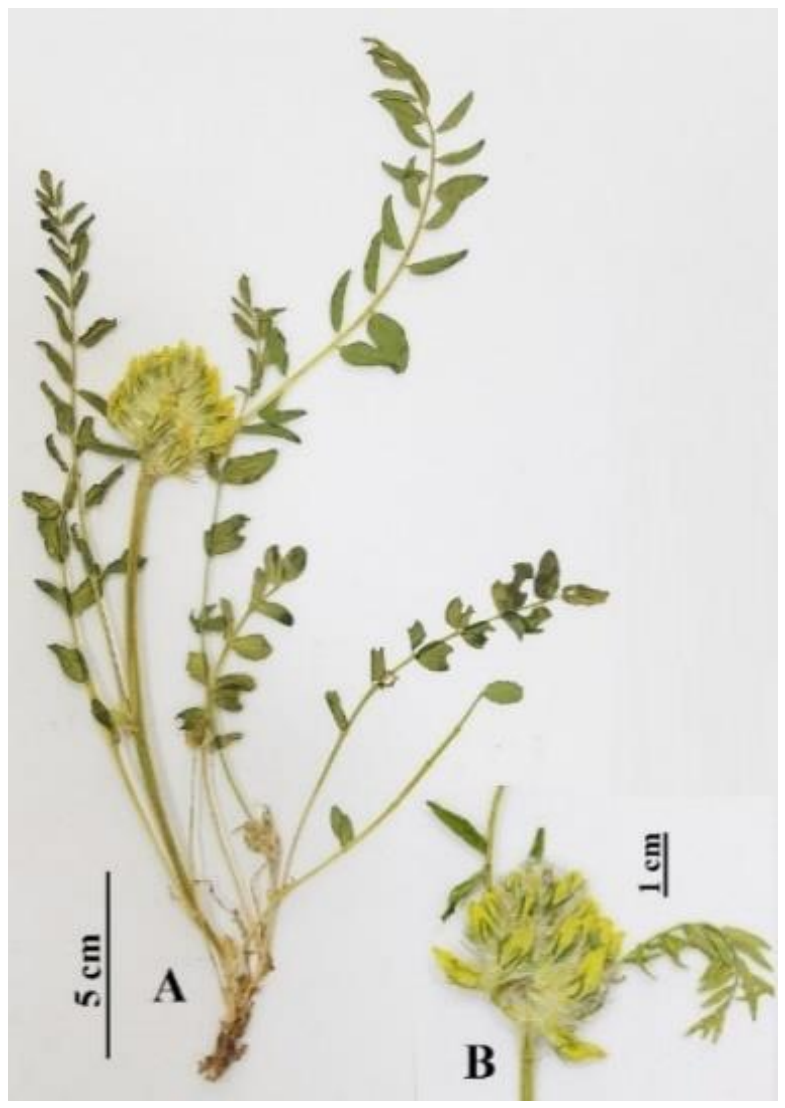

Figure 3. Astragalus aytatchii - A. Habit, B. Inflorescence. 
Specimens examined: A3 Ankara: Beypazarı, between Kırbaşı and Uşakbükü villages, 36 T 395037-4429963, 810 m, gypsum-bearing and salty slopes, 11.6.2016, Koç 2313 \& Hamzaoğlu (GAZI, ANK).

According to the distribution information given in the Flora of Turkey and the East Aegean Islands, the species is an endemic grown in the surroundings of Tuz Lake on the salty marshes (Aksaray and Konya) (Hedge, 1982). When it is compared with the depiction given in the work, it was determined that the number of flowers found in the verticillates in the Beypazarı specimens is generally 3-4 each (not 4-6) and that the length of the leaves was longer (Fig. 4). The extent of the area of distribution of taxon became approximately $4000 \mathrm{~km}^{2}$ together with the Beypazarı population, which was determined at a bird'seye view of approximately $200 \mathrm{~km}$ to the northwest according to Tuz Lake (Fig. 5). While the species is growing on very slightly sloped salty marshes at Tuz Lake, it was determined on the slope of a hill with gypsum, which has water seepage at Beypazar1. On the area of the species determined in the Beypazar1, species, which are frequently observed in the surroundings of Tuz Lake, were also encountered, such as Onosma halophila Boiss. \& Heldr., Taraxacum farinosum Hausskn. \& Bornm. ex Hand.Mazz., and Gypsophila oblanceolata Barkoudah. Furthermore, a new species Hypericum turcicum Özbek \& Hamzaoğlu from the area, was published recently (Özbek et al., 2019).

\section{Crassulaceae}

Sedum hewittii Chamberlain., Notes. Roy. Bot. Gard. Edinburgh 31(2): 325 (1972), (IPNI, 2020).

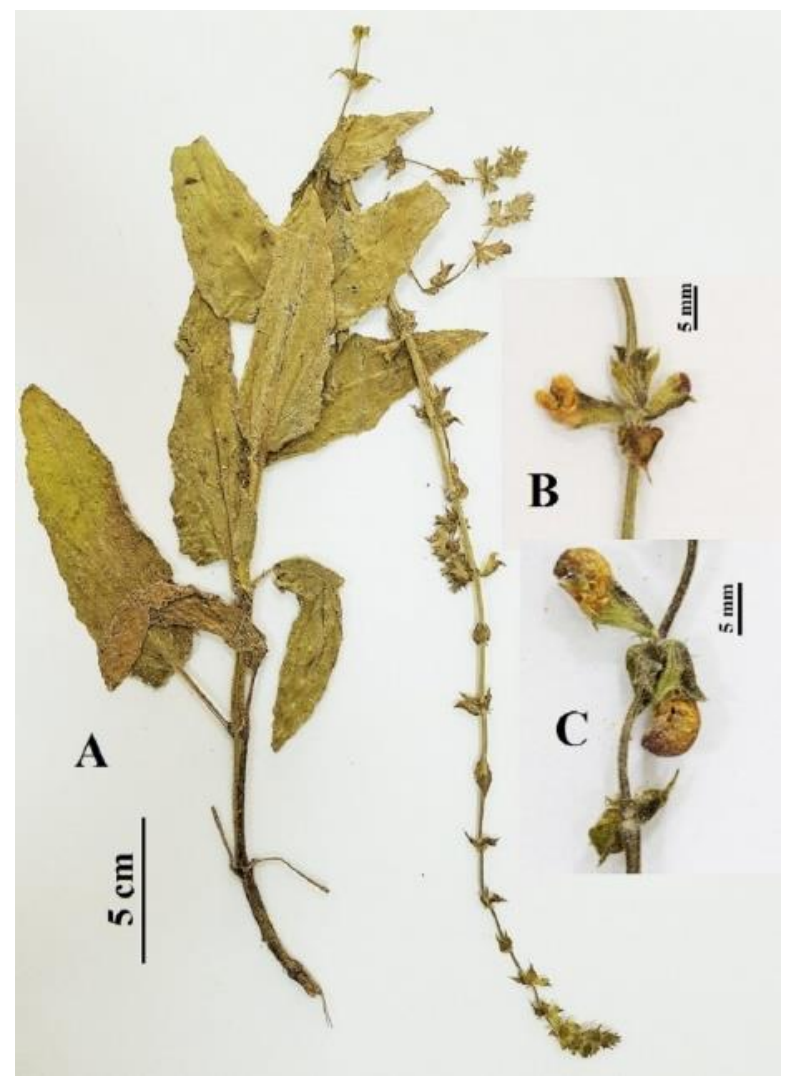

Figure 4. Salvia halophila - A. Habit, B and C. Inflorescence.

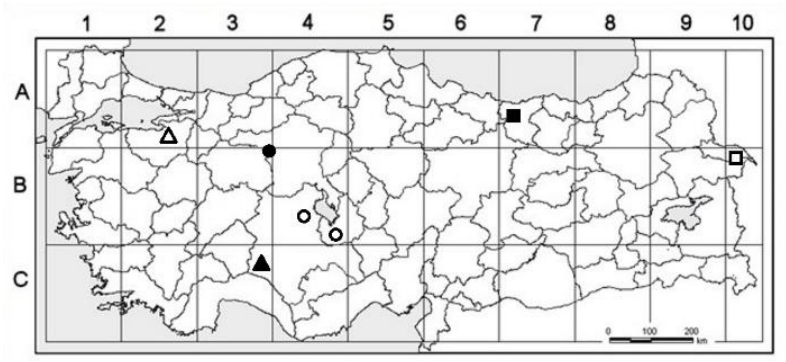

Figure 5. The known populations of Salvia halophila $(\mathbf{O})$ and the newly determined populations $(\mathbf{O})$, the known populations of Sedum hewittii $(\boldsymbol{\square})$ and the newly determined populations $(\boldsymbol{\square})$, the known populations of Senecio olympicus $(\triangle)$ and the newly determined populations $(\boldsymbol{\Delta})$.

Specimens examined: A7 Giresun: Dereli, SW. of Aksu village, Karagöl Mountain, towards the summit of Kılınçtepe, 37 T 428850-4486785, 3000 m, rocky slopes, 9.8.2008, Hamzaoğlu 5315 \& Koç (GAZI).

According to the distribution information given in the Flora of Turkey and the East Aegean Islands, the species is an endemic that is only growing at Ağr1 Mountain (Chamberlain, 1972). Together with the Karagöl (Dereli, Giresun) population, which was determined approximately $530 \mathrm{~km}$ to the west-northwest compared to Ağrı Mountain

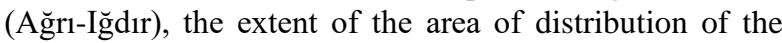
taxon has become approximately $6000 \mathrm{~km}^{2}$ (Fig. 5 and 6). Sedum hewittii grows at Ağr1 Mountain between 2750-3050 meters, on volcanic bedrock and moist areas. The newly determined population displays a similarity to the Ağrı Mountain population from the aspect of these characteristics.

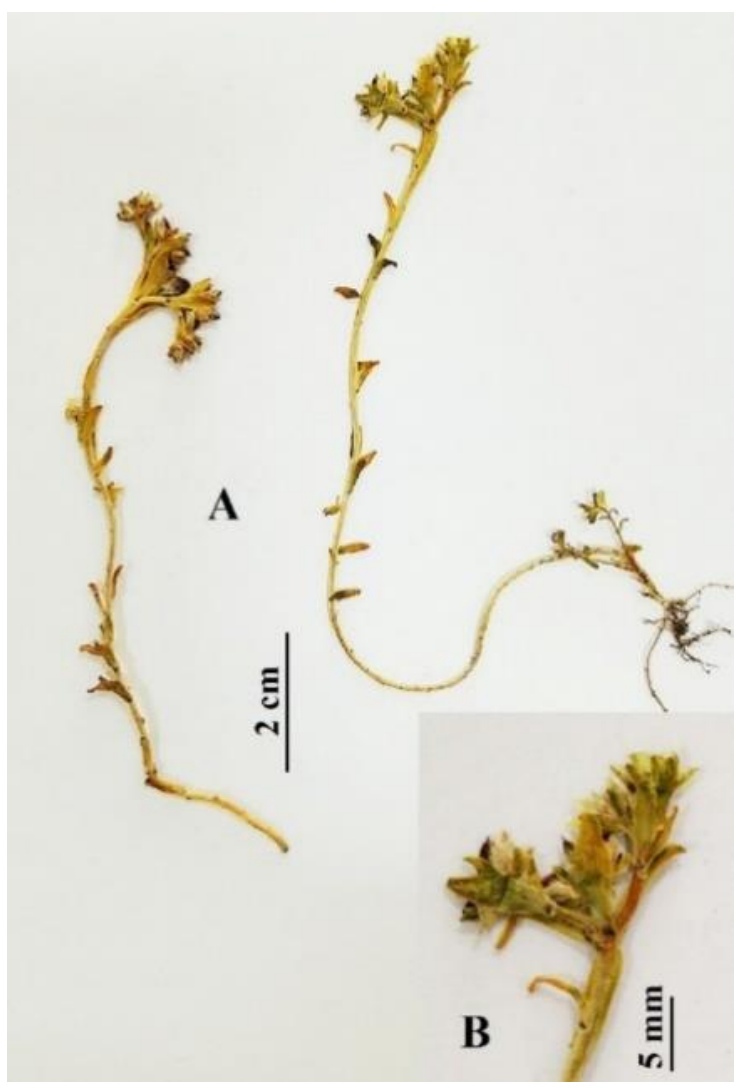

Figure 6. Sedum hewittii - A. Habit, B. Inflorescence. 


\section{Asteraceae}

Senecio olympicus Boiss., Diagn. Pl. Orient. ser 1(4): 13 (1844), (IPNI, 2020).

Specimens examined: C3 Konya: Between Seydişehir and Derebucak district, west of Taraşçı villag, left of Rezebeli Pass, towards the summit, $36 \mathrm{~S} 385253-4145410,2140 \mathrm{~m}$, calcareous rocks, 14.7.2011, Hamzaoğlu 6167 \& Koç (GAZI).

According to the distribution information given in the Flora of Turkey and the East Aegean Islands, the species is an endemic only growing at Uludağ (Bursa) (Matthews, 1975). The population was determined at Rezebeli Pass at a bird's eye view of approximately $390 \mathrm{~km}$ to the southsoutheast of the Uludag population (Fig. 5 and 7). The extent of area of distribution of the taxon has become approximately $3000 \mathrm{~km}^{2}$ with this new population. The edges of the lower leaves in the individuals belonging to the Rezebeli population are smooth (not remotely repanddenticulate). The continuousness and the taxonomic importance of this morphological difference should be discussed by examining in detail more individuals.

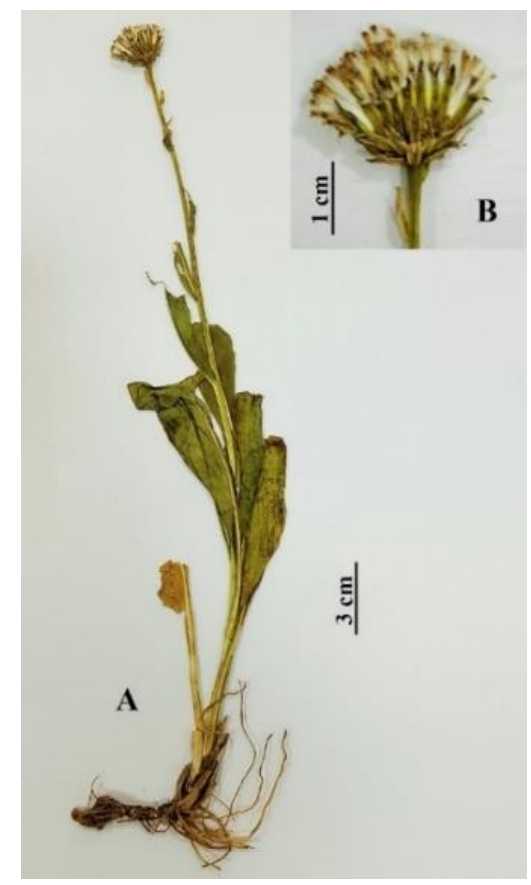

Figure 7. Senecio olympicus - A. Habit, B. Capitulum.

\section{References}

Akan H, Civelek Ş (2001). Astragalus aytatchii (Fabaceae), a new species from Anatolia, Turkey. Annales Botanici Fennici 38(3): 167-170.

Chamberlain DF (1972). Sedum L. In: Davis PH (Ed.). Flora of Turkey and the East Aegean Islands. Vol. 4. Edinburgh: Edinburgh University Press. pp. 224-243.

Hedge IC (1965). Aethionema L. In: Davis PH (Ed.). Flora of Turkey and the East Aegean Islands. Vol. 1. Edinburgh: Edinburgh University Press. pp. 481-485.

Hedge IC (1982). Salvia L. In: Davis PH (Ed.). Flora of Turkey and the East Aegean Islands. Vol. 7. Edinburgh: Edinburgh University Press. pp. 400-461.

IPNI (2020). International Plant Names Index. Published on the Internet http://www.ipni.org, The Royal Botanic Gardens, Kew, Harvard University Herbaria \& Libraries and Australian National Botanic Gardens. Available from: https://www.ipni.org / [accessed 01 October 2020].

IUCN Standards and Petitions Committee (2019). Guidelines for Using the IUCN Red List Categories and Criteria. Version 14. Prepared by the Standards and Petitions Committee. Committee. Available from: http://www.iucnredlist.org/documents/ RedListGuidelines.pdf / [accessed 01 October 2020].

Matthews VA (1975). Senecio L. In: Davis PH (Ed). Flora of Turkey and the East Aegean Islands. Vol. 5. Edinburgh: Edinburgh University Press. pp. 145-168.

Özbek MU, Koç M, Hamzaoğlu E (2019). Contributions to the Hypericum L. section Oligostema (Boiss.) Stef. (Hypericaceae), and Hypericum turcicum sp. nov. as a new species from Turkey. Turkish Journal of Botany 43(5): 694-70.

Vural M, Adıgüzel N (1995). A new species from Central Anatolia - Aethionema dumanii (Brassicaceae). Turkish Journal of Botany 19(4): 481-483. 